\title{
The para-chloroaniline prevention after the use of sodium thiosulfate as an intermediary irrigator between sodium hypochlorite and chlorhexidine
}

Luis Felipe Coutrin de Toledo ${ }^{1}$, Cristiane de Souza Siqueira Pereira ${ }^{2}$, Evelyn Oliveira de Paulo Barreto França ${ }^{3}$, Thamires Chagas de Medeiros $^{4}$, Marco Orsini ${ }^{5}$, Marco Azizi ${ }^{6}$, Jacqueline Fernandes do Nascimento ${ }^{7}$, Michelle Paiva Weydt Galhardi ${ }^{8}$, Vivian Ronquete ${ }^{9}$, Pablo Amoroso-Silva ${ }^{10}$ and Marília Fagury Videira Marceliano-Alves ${ }^{11^{*}}$

${ }^{1}$ Department of Endodontics, Vassouras University, Vassouras, Rio de Janeiro, Brazil. Email: odontoledo@ hotmail.com

${ }^{2}$ Department of Chemical Engineering Vassouras University, Vassouras, Rio de Janeiro, Brazil. Email: crispereirauss@ gmail.com

${ }^{3}$ School of Dentistry, Iguaçu University, Nova Iguaçu, Rio de Janeiro, Brazil. Email: evelynfranca92@gmail.com

${ }^{4}$ School of Dentistry, Rio de Janeiro Federal University, Rio de Janeiro, Brazil. Email: thamirescmedeiros@gmail.com

${ }^{5}$ Medical School, Iguaçu University, Nova Iguacu, Rio de Janeiro, Brazil. E-mail: orsinimarco@ hotmail.com

${ }^{6}$ Medical School, , Iguaçu University, Nova Iguacu, Rio de Janeiro, Brazil. Email: marcoazizi@oi.com.br

${ }^{7}$ Medical school graduate, Iguaçu University, Nova Iguaçu, Brazil. Email: jac.fn@ hotmail.com

${ }^{8}$ Department of Dental Materials, Iguaçu University, Nova Iguaçu, Rio de Janeiro, Brazil. Email: michelleweydt@gmail.com

${ }^{9}$ Department of Endodontics, Iguaçu University, Nova Iguaçu, Brazil. Email: v.ronquete @ hotmail.com

${ }^{10}$ Departament of Restorative Dentistry, Londrina State University, Londrina, Brazil email: pablo_amoroso@hotmail.com

${ }^{11}$ Department of Endodontics, Iguaçu University, Nova Iguaçu, Brazil, Email: mmarceliano@ hotmail.com

*Corresponding Author: Marília FaguryMarceliano-Alves, Department of Endodontics, Iguaçu University, Nova Iguaçu, Av. Abílio Augusto Távora, 2134 Nova Iguaçu - RJ Brazil Zip: 26260-045 Phone numbers: +55 21 99900-6707.Email: mmarceliano@ hotmail.com

Received date: August 04, 2020; Accepted date: August 25, 2020; Published date: Sepłember 01,2020

Citation: Luis Felipe Coutrin de Toledo, Cristiane de Souza Siqueira Pereira, Evelyn Oliveira de Paulo Barreto França, Thamires Chagas de Medeiros, Marco Orsini, Marco Azizi, Jacqueline Fernandes do Nascimento, Michelle Paiva Weydt Galhardi, Vivian Ronquete, Pablo Amoroso-Silva and Marília Fagury Videira Marceliano-Alves. (2020), The para-chloroaniline prevention after the use of sodium thiosulfate as an intermediary irrigator between sodium hypochlorite and chlorhexidine J. Endocrinology and Disorders 4(1);DOI: 10.31579/2640-1045/051

Copyright: (c) 2020, Marília FaguryMarceliano-Alves, This is an open access article distributed under the Creative Commons Attribution License, which permits unrestricted use, distribution, and reproduction in any medium, provided the original work is properly cited.

\section{Abstract}

Objective: Evaluating the neutralization of sodium hypochlorite $(\mathrm{NaOCl})$ by sodium thiosulfate in vitro, in different concentrations, in the prevention of para-chloroaniline (PCA) formation when in contact with CHX. Material and methods: It were collected $2 \mathrm{~mL}$ of $\mathrm{NaOCl}$ solution to $2.5 \%$ and to $6 \%$, divided in eight groups according to the sodium thiosulfate concentration $(1.0 ; 2.5 ; 5.0 ; 10 \%)(\mathrm{TSF})$. The tests were done in duplicate and in each plate, it was poured $2 \mathrm{~mL}$ of TFS and the reaction was observed for 5 minutes. After, $2 \mathrm{~mL}$ of $2 \%$ Chlorhexidine (CHX) were pouring on the plates to verify the formation of PCA. The infrared spectroscopy with Fourier transform was used to verify the presence of PCA, and, in each solution, the $\mathrm{pH}$ was verified with universal strip.

Results: All analyzed samples presented presence of water and deuterium water, and there was not identification of the PCA presence. The $\mathrm{pH}$ result of the solutions was between 8 and 9. It was verified that in the increasing of the concentration of the TFS there was gradual formation of precipitated compound and increase of the turbidity of the final sample.

Conclusion: TFS can be used as an intermediate irrigation solution to prevent the formation of para-chloroaniline in the combined use of $\mathrm{NaOCl}$ and $\mathrm{CHX}$.

Keywords: brown precipitate, chlorhexidine, irrigators, infrared spectrometry, para-chloroaniline, sodium hypochlorite

Running tittle: sodium thiosulfate as a para-chloroaniline prevention

\section{Introduction}


The disinfection of the root canal system (RCS) is a fundamental factor in the endodontic therapy for the reduction of the number of microorganisms that is in the necro pulpectomy techniques and then collaborating to the maintenance of the healthy peri-root tissues or favor this region recuperation when that is a lesion (Siqueira et. al. 2017). The endodontic infections are caused by bacterial intra-root biofilms colonizing mainly the light of the main canal. Bacteria have the power of propagating into the dentin tubules, apical ramifications, lateral canals, isthmus and irregularities. Although the chemical-mechanical prepare is capable to eliminate a large quantity of micro-organisms, a complete disinfection is hard due to the complex anatomy of the RCS [1.2].

The action of the endodontic instruments during the instrumentation occurs only in the light of the main canal and it does not fully achieve the system of root canals. Thus, the using of an auxiliary chemical substance during the chemical mechanical prepare is especially important and aims to reach inaccessible areas to the instruments, to promote the additional elimination of microorganisms of the endodontic complex. The physical action of the irrigator liquid promotes the hydraulic circulation into the root canal, dragging tissues, microorganisms, and dentin scrapings [2]. The chemical action of the irrigator substance should have the property of causing the bacteria and fungi death [4].

The effectiveness of the irrigation can be impaired due to the anatomic complexity of the root canal, that impedes the contact of the auxiliary substance with the tissues or micro-organisms, speed in the instrumentation that reduce the time of permanence of the substance into the canal, the short volume of the substance that a canal may contain and the deficient renew of the chemical substance during the prepare of the root canal. The authors related that the success of the endodontic therapy rest on three important bases: the chemical-mechanical prepare, the control of infection and filling of the root canals. They still highlighted that we should eliminate all the residue and micro-organisms into the root canals and that the action of an auxiliary chemical substance depends of factors as the contact area between the chemical substance and the pathogens, as the time of the action into the canal [5].

Some authors advocate the using of the intra-canal medication to the additional elimination of micro-organisms, which present significant result [6-8]. However, the using of the intra-canal medication presents the disadvantage of the need to add minimally a second session in the therapeutic attendance.

Aiming to eliminate additional consults, some procedures objective to maximize the effects of the chemical mechanical prepare immediately after its conclusion, disregarding the using of intra-canal medication, to the treatment can be done in an unique session with high incidence of negative cultures in the filling act and, then, with higher power of success [8].

Worldwide, the Sodium Hypochlorite $(\mathrm{NaOCl})$ is considered the main endodontic irrigator, and this choice is related to its efficient antimicrobial capability and of alive or necrotic pulp tissues dissolution [9]. Associations of other solutions with the $\mathrm{NaOCl}$ in alternate use, during the irrigation, have been proposed with the objective to maximize the bacterial elimination of the root canal. (Siqueira et. al. 2002). About the handling that is highlighted, the final irrigation with $\mathrm{CHX}$ (CHX) 2\% seems to be one of the most promising [10-11].

It occurs that the irrigation with $\mathrm{NaOCl}$ during the chemical mechanical prepare leave the residues of this substance adhered to the dentin walls and the sequential irrigation with $\mathrm{CHX}$ may generate the formation of a strong brown pigment native of the reaction between $\mathrm{NaOCl}$ and $\mathrm{CHX}$ called para-chloroaniline (PCA) [12].

Several articles evaluated the combined irrigation of the $\mathrm{NaOCl}$ and $\mathrm{CHX}$ and observed the formation of the PCA compound and for this reason unbutton this combined use in the irrigation of root canals [12-14]. Considering the possibility of disabling the chlorine content of the $\mathrm{NaOCl}$, some substances were testes, as EDTA $17 \%$ and saline. However, between the evaluated substances, the most recommended has been TFS $[16,17]$.

Based in the data of previous studies, it is recommended to have caution using an intermediary irrigator between $\mathrm{NaOCl}$ and $\mathrm{CHX}$ preventing the formation of PCA precipitation $[14,15]$. Thus, the aim of this study is to evaluate the using of TFS in different concentrations and these effects in the prevention of PCA in vitro formation when mixed to $\mathrm{NaOCl}$ in different concentrations. Consequently, when it occurs the disable of the $\mathrm{NaOCl}$, it will be available the combined irrigation with CHX without formation of any precipitates and favoring the benefits of the synergic antimicrobial action through the irrigation of $\mathrm{NaOCl}$ and CHX.

\section{Material and methods}

The $2.5 \% \mathrm{NaOCl}, 6 \% \mathrm{NaOCl}, 2 \% \mathrm{CHX}$ and different concentrations of TFS $(1.0 ; 2.5 ; 5.0 ; 10 \%)$ solutions were manipulated in magistral pharmacy, for the neutralization evaluation of $\mathrm{NaOCl}$ and $\mathrm{CHX}$ tests. All the used solutions were tested to verify the chloride presence using the infrared spectroscopy with Fourier transformer to serve as standard (Figure 1 and chart 1).
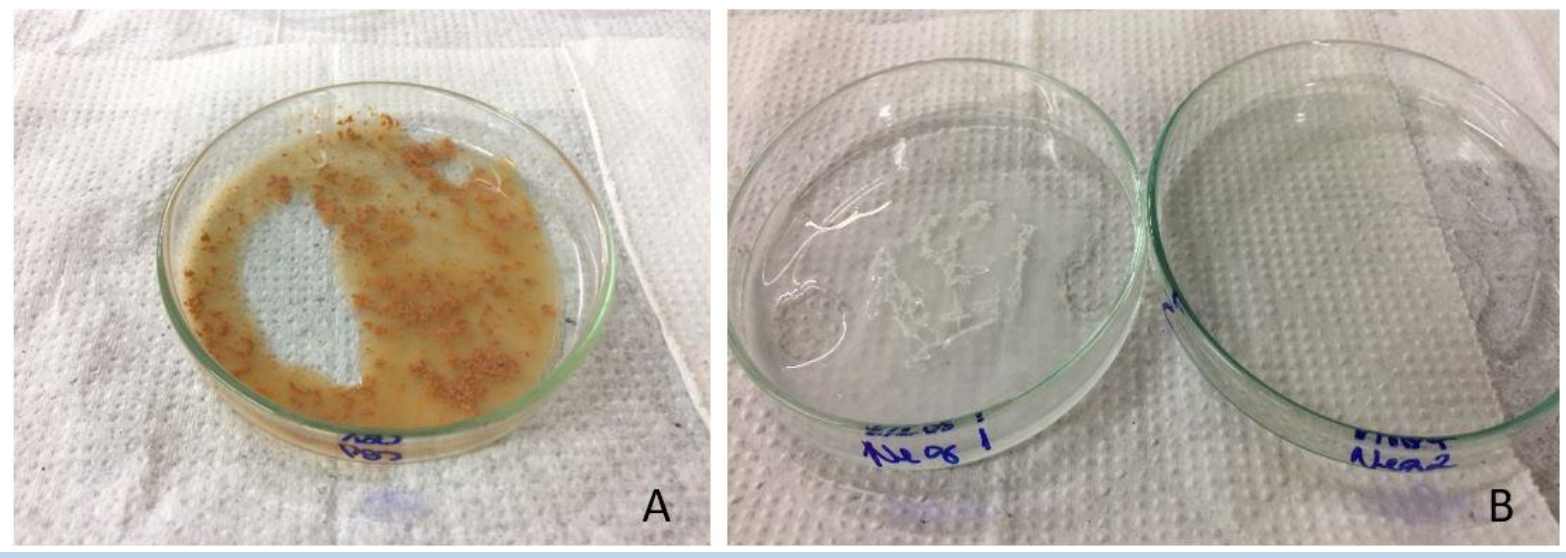

Figure 1. Comparative sample to positive test (A) and for the negative 1 and 2 tests (B). 


\begin{tabular}{lll}
\hline \multicolumn{1}{c}{ Test } & \multicolumn{1}{c}{ Solution 1 } & \multicolumn{1}{c}{ Solution 2 } \\
\hline Positive & $6 \% \mathrm{NaOCl}$ & $2 \% \mathrm{CHX}$ \\
Negative 1 & $10 \% \mathrm{TFS}$ & $2 \% \mathrm{CHX}$ \\
Negative 2 & $6 \% \mathrm{NaOCl}$ & $10 \%$ TFS \\
\hline
\end{tabular}

Chart 1. Composition of

Negative 2

tests.

To the positive test, the $\mathrm{NaOCl}$ and $\mathrm{CHX}$ solutions were mixed and it was observed a brown product formation that is supposedly considered PCA, after the 5 minutes of observation period (Figure 1A). The negative test represents the chloride disable that can occur in two different relations, depending of the TFS concentration (Figure 1B). The Table 1 presents the composition of the samples destined to the previously cited tests. The product solutions were taken to the infrared spectroscopy with Fourier transform (FTIR) to evaluation in chloride presence.

\begin{tabular}{cll}
\hline Group & \multicolumn{1}{c}{ Solution 1 } & \multicolumn{1}{c}{ Solution 2 } \\
\hline 1 & $2,5 \% \mathrm{NaOCl}$ & $1,0 \%$ TFS \\
2 & $2,5 \% \mathrm{NaOCl}$ & $2,5 \%$ TFS \\
3 & $2,5 \% \mathrm{NaOCl}$ & $5,0 \%$ TFS \\
4 & $2,5 \% \mathrm{NaOCl}$ & $10,0 \%$ TFS \\
5 & $6,0 \% \mathrm{NaOCl}$ & $1,0 \%$ TFS \\
6 & $6,0 \% \mathrm{NaOCl}$ & $2,5 \%$ TFS \\
7 & $6,0 \% \mathrm{NaOCl}$ & $5,0 \%$ TFS \\
8 & $6,0 \% \mathrm{NaOCl}$ & $10,0 \%$ TFS \\
\hline
\end{tabular}

Chart 2. Division of experimental groups for analysis.

For each group, $2 \mathrm{~mL}$ of $\mathrm{NaOCl}(2.5$ or $6 \%)$ were deposited in Petri plates and, after, it was poured $2 \mathrm{~mL}$ of the TFS solution (concentrations in test). The reaction was observed for 5 minutes, with a digital chronometer to mark the intervals of application between the substances. After 5 minutes of the first mixture it was added $2 \mathrm{~mL}$ of CHX $(2 \%)$, when it was observed visual if it was formation of PCA. The procedure was performed to all the TFS in test concentrations.

The analysis of the chloride presence, component of PCA, in the final solutions was performed by infrared spectroscopy with Fourier transformer (FTIR) that used as basis wave standard length to the identification of a possible presence of water and PCA. The appliance gives a graphic whose peaks are compared with a data bank of the equipment library. The chloride total concentration was evaluated with the chloride set use (Kit Vacu-Vials, Midland, United States) and standard samples were used as visual comparative parameter, one that contains solution in a pink coloration that means the chloride presence and other containing a colorless solution that means the chloride absence. The $\mathrm{pH}$ of the final samples has been also evaluated with universal $\mathrm{pH}$ indicator strip (Kasvi, São José dos Pinhais, Brasil), because the formed volume does not enough to the analysis in pHmeter.

The infrared spectroscopy with Fourier transformer gives data to the identification of the chemical composing from the measuring the vibration of molecules by the unfolding of the connections. To this analysis it was used as basis wave standard lengths to identify possible presences of water and PCA.

\section{Results}

The Table 1 presents results obtained to the $\mathrm{pH}$ test of the solutions before the analysis accomplishment.

\begin{tabular}{lll}
\hline & Solution & $\mathbf{p H}$ \\
\hline $2,5 \% \mathrm{NaOCl}$ & & 9,34 \\
$6 \% \mathrm{NaOCl}$ & 9,92 \\
$1 \% \mathrm{TFS}$ & & 8,94 \\
$2,5 \% \mathrm{TFS}$ & 7,85 \\
$5 \% \mathrm{TFS}$ & 7,72 \\
$10 \% \mathrm{TFS}$ & 7,65 \\
$2 \% \mathrm{CHX}$ & 9,85 \\
\hline
\end{tabular}

Table 1. Results of $\mathrm{pH}$ to the solutions used in the tests.

After the tests, it was verified that there was not formation of the samples. The found results to the $\mathrm{pH}$ and chloride tests are presented in the Table 4. pink coloration in the chloride set, highlighting the chloride absence in

\begin{tabular}{ccc}
\hline Group & pH & Chlorine \\
\hline 1 & 8 & absent \\
2 & 9 & absent \\
3 & 8 & absent \\
4 & 8 & absent \\
5 & 9 & absent \\
6 & 9 & absent \\
7 & 8 & absent \\
8 & 9 & absent \\
\hline
\end{tabular}

Table 2. Results of the $\mathrm{pH}$ and chlorine of final samples. 
It was verified that according to the increasing of TFS concentration there was gradual formation of precipitated and increasing of the turbidity of the final sample. The tests were done in duplicate to ensure the analytical reliability of the data (Figures 2 and 3).
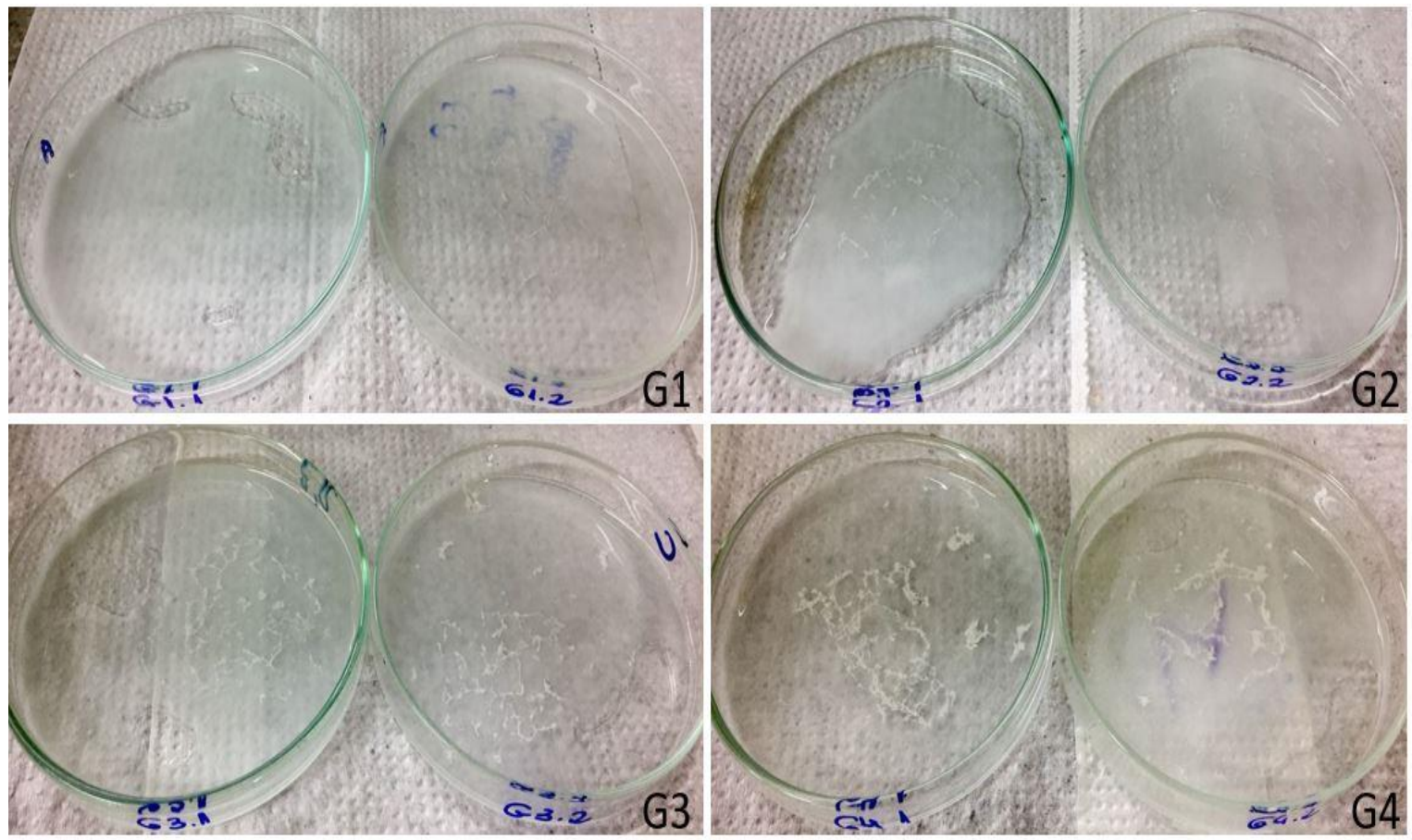

Figure 2. Experimental groups when used $2.5 \% \mathrm{NaOCl}$ concentration.
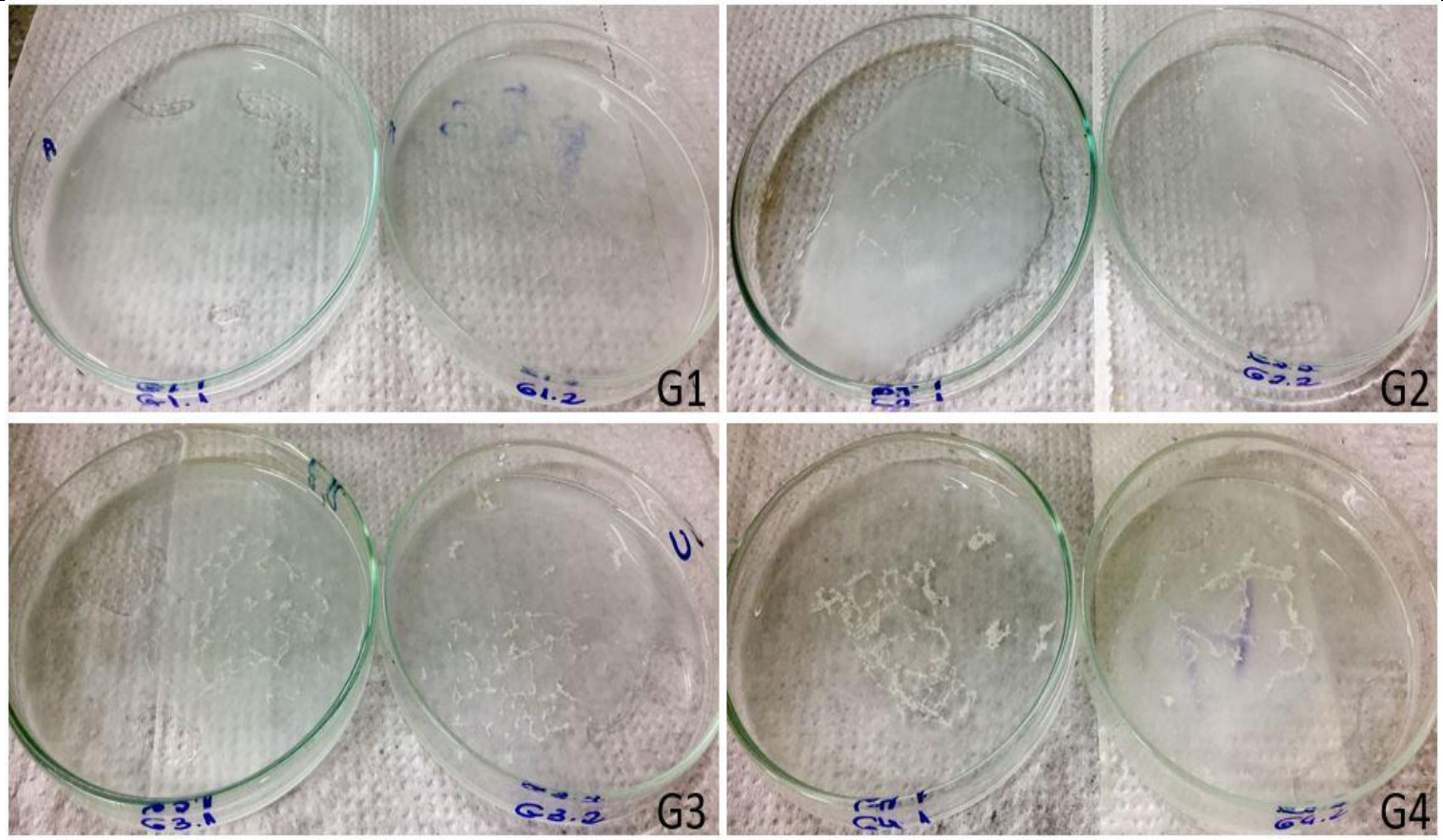

Figure 3. Experimental groups when used $6 \% \mathrm{NaOCl}$ concentration.

During the verification by the infrared spectroscopy method the results are expressed through curves and graphics. All the analyzed samples presented correspondent curves, with hardly considerable dispersion. It was obtained as result only the presence of water and deuterium water that is the presence of undefined compounds in aqueous medium. Those are considered undefined compounds because there was not identification of PCA presence. The figures 13 and 14 expresses the comparison of the curve characteristics between the analyzed samples and between the water standard (Graphic 1). 


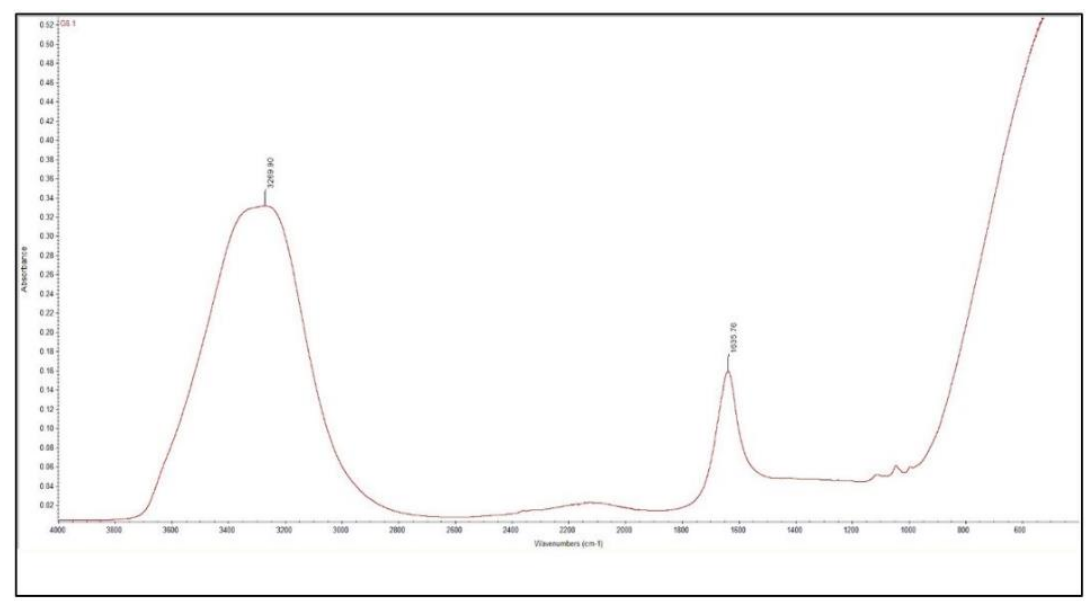

Figure 4. Representative graphic of the infrared spectroscopy demonstrating the curves and peaks of the positive control samples, demonstrating PCA absence.

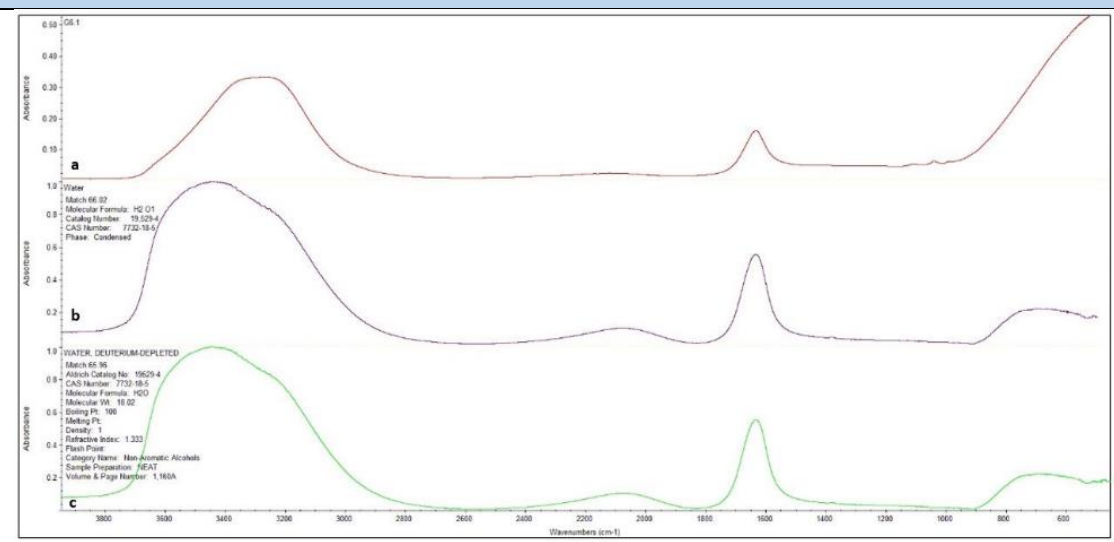

Figure 5. Representative graphic of the infrared spectroscopy demonstrating the para-chloroaniline absence curves (a), water (b) and deuterium water presence (c).

\section{Discussion}

Between the procedures involved in the endodontic infection, the irrigation can play an important role in the elimination of microorganisms elimination in the root canal. Irrigators are used during the endodontic treatment to eliminate the loose debris, lubricating the dentin walls, dissolving organic material in the canal, and actuating as an antimicrobial $[18,19]$.

The cleaning and disinfection of procedures into the root canal systems are highly dependent of the mechanical and chemical effects of the irrigators. The mechanical effects during the irrigation are generated by the flux and re-flux of the irrigator solution in the root canal. Independently of the used irrigator type, the bacterial population into the canal is significantly reduced by the mechanical effects of the irrigation [20]. The chemical properties with antimicrobial effects of the irrigator solution may significantly help the mechanical effects to eliminate microorganisms $[18,19]$.

Until the present date, $\mathrm{NaOCl}$ has been used worldwide as irrigator in the endodontic and no studies so far demonstrated other more efficient substance. Between the main characteristics of $\mathrm{NaOCl}$, it is highlighted the effective antimicrobial activity of broad spectrum, capable to eliminate quickly vegetative bacteria, spore-forming bacteria, fungi, protozoa, virus and bacterial spores. Other irrigator substances and different strategies have been proposed to improve the cleaning and the antimicrobial capacity of the chemical mechanical preparation [13, 20]. An irrigator strategy commonly recommended is the $\mathrm{NaOCl}$ and $\mathrm{CHX}$ association [14, 20, and 21]. However, the formation of a precipitated called PCA can form when occurs the contact between $\mathrm{NaOCl}$ and $\mathrm{CHX}$ [14].

Studies evaluating PCA formation suggest that the combination $\mathrm{NaOCl}$ and $\mathrm{CHX}$ may be avoided due to the emergence of the reagent to this mixture [13-15]. However, there are studies that highlight that this combination more effective to eliminate micro-organisms when one of the substances is applied in isolation [10,22].

As in other studies [23, 24]. It seems like a smart idea to apply $\mathrm{NaOCl}$ initially in the canal irrigation during endodontic therapy and using the benefits that this substance can offer in a moment that is very important to dissolve organic tissues, to eliminate micro-organisms and their products. Ended the chemical mechanical prepare with $\mathrm{NaOCl}$, to irrigate the canals with $\mathrm{CHX}$ and in the same form seize the properties of this substance, highlighting the bactericidal potential in the medium term due to the substantivity, will contribute to a bigger elimination of possible irrigators that stay viable after the instrumentation is completed. Therefore, it is interesting to combine the $\mathrm{NaOCl}$ and $\mathrm{CHX}$ properties, without any precipitate been formed and there is no risk to the patient health. To neutralize the $\mathrm{NaOCl}$ before the use of $\mathrm{CHX}$ can present significant antimicrobial advantages.

In dentistry, TSF is constantly employed in the $\mathrm{NaOCl}$ neutralization, but without a protocol of use defined [24-31]. This study evaluated different variables in the disable process of $\mathrm{NaOCl}$ by TSF. Different concentrations of the samples were tested in a same volume in relation of time. It was identified possible variation of $\mathrm{pH}$, after the mixture was done and the presence or not of residual chloride. A similar 
study was performed; however, it did not assess variable analysis during the time, $\mathrm{pH}$ or presence of chloride ions in the final precipitate [32].

TSF was efficient neutralizing $\mathrm{NaOCl}$ in all samples, even when the shorter concentration of TSF (1\%) was applied on the higher concentration of $\mathrm{NaOCl}(6 \%)$. The $\mathrm{pH}$ of the final samples varies between 8 and 9 (alkaline). When most of the micro-organisms involved in the endodontic infections do not reproduce in alkaline environment [33-36], possible residues into RCS will not favor the multiplication of pathogens.

The use of TSF to neutralize solutions of $\mathrm{NaOCl}$ with an 8 to 10 $\mathrm{pH}$, can result in the formation of shorter levels of chlorate [34-36]. The chlorate is a contaminant that can be present in the water and is in the list of undesirable substances of the Environmental Protection Agency of United States. The authors analyzed the $\mathrm{NaOCl}$ neutralization to $8.25 \%$ for 5 minutes. The $\mathrm{pH}$ of the samples after the mixture varied from 8 to 9 . The authors highlighted that as higher TSF concentration, higher the whitish turbidity of the final sample, as also the presence of a characteristic sulfur odor was higher [34-36]. In this study, was not evaluated the presence of chlorate in the samples, and neither the turbidity of the samples quantitatively or qualitatively neither the generated odor, although both were noted. Only water and deuterium water could be identified in the final samples of this study.

Another study also assessed if PCA is formed by the reaction of mixture of $\mathrm{NaOCl}$ and $\mathrm{CHX}$ using different analyze techniques as highly efficient liquid chromatography, spectroscopy of nuclear magnetic resonance of protons, gas chromatography, thin-layer chromatography, spectroscopy in the infrared region and mass spectrometry. To obtain the brown precipitate, it was mixed $4.99 \% \mathrm{NaOCl}$ with $2.0 \%$ chlorhexidine. The brown precipitate was analyzed and compared to signals obtained from $4.99 \% \mathrm{NaOCl}$ solutions commercially available, $2 \%$ solutions and 98\% PCA in the form of powder. After studies, the authors observed that the chromatographic and spectroscopic analysis demonstrates that the brown precipitate do not contains free PCA [35, 36].

\section{Conclusion}

The use of TSF intermediary between $\mathrm{NaOCl}$ and $\mathrm{CHX}$ prevented PCA formation in all samples. The application of TSF in the shortest concentration (1\%) for 5 minutes was demonstrated as enough to prevent PCA formation when $2 \% \mathrm{CHX}$ was added on $\mathrm{NaOCl}$, even in the highest tested concentration (6\%). The interaction of $\mathrm{NaOCl}$ and $\mathrm{CHX}$ forms an insoluble precipitate. It is considered prudent to prevent the formation of this precipitate using intermediary flushes of TSF in volumes of minimally $2 \mathrm{~mL}$ to neutralize the $\mathrm{NaOCl}$ before using $\mathrm{CHX}$ as a final irrigator. New studies varying time of action and concentration of TSF may be performed aiming to better clarify the possible variables of neutralization.

\section{Acknowledgements}

This study was supported by grants from Fundação Carlos Chagas Filho de Amparo à Pesquisa do Estado do Rio de Janeiro (FAPERJ), Brazilian Governmental Institution.

\section{Conflict of interest}

The authors deny any conflict of interest.

\section{References}

1. Siqueira Junior JF, Rôças IDN, Marceliano-Alves MF, Pérez AR, Ricucci D (2018). Unprepared root canal surface areas: causes, clinical implications, and therapeutic strategies. Braz Oral Res. Oct 18; 32(suppl 1):e65.
2. Siqueira JF Jr, Rôças IN (2010). Microbiology and treatment of endodontic infections. In: Hargreaves, K. M.Cohen, S. (Ed.). Cohen's pathways of the pulp. St. Louis: Mosby/Elsevier, 559600 .

3. Gomes BP, Ferraz CC, Vianna ME, Berber VB, et. al. (2001). In vitro antimicrobial activity of several concentrations of sodium hypochlorite and chlorhexidine gluconate in the elimination of Enterococcus faecalis. Int Endod J. 34, n.6, 424-428.

4. Krishnamurthy S, Sudhakaran S. (2010). Evaluation and prevention of the precipitate formed on interaction between sodium hypochlorite and chlorhexidine $\mathrm{J}$ Endod. Jul; 36(7):1154-7.

5. Siqueira, JF, Jr., Alves, FR, Versiani, MA, et al. (2013). Correlative bacteriologic and microcomputed tomographic analysis of mandibular molar mesial canals prepared by selfadjusting file, Reciproc, and Twisted File systems J Endod. 39:1044-1050.

6. Anthony, DR, Gordon, TM, del Rio, CE. (1982); The effect of three vehicles on the $\mathrm{pH}$ of calcium hydroxide. Oral Surg Oral Med Oral Pathol. 54:560-565.

7. Oliveira JC, Alves FR, Uzeda, M, et al. (2010). Influence of serum and necrotic soft tissue on the antimicrobial effects of intracanal medicaments. Braz Dent J. 21:295-300.

8. Siqueira, JF, Jr., Rôças, IN, Paiva, SS, et al. (2007). Bacteriologicinvestigation of theeffects of sodiumhypochlorite and chlorhexidineduringtheendodontictreatment of teethwith apical periodontitis. Oral Surg Oral Med Oral Pathol Oral Radiol Endod.;104:122-130.

9. Clarkson RM, Moule AJ. (1998). Sodium hypochlorite and its use as na irrigant. Aust Dent J 43:250-256.

10. Zamany, A, Safavi, K, Spångberg, LS. (2003). The effect of chlorhexidine as an endodontic disinfectant, Oral Surg Oral Med Oral Pathol Oral RadiolEndod. ; 96:578-581.

11. Rôças IN, Siqueira JF Jr. (2011b). In vivo antimicrobialeffects of endodontictreatment procedures as assessedby molecular microbiologictechniques J Endod.; 37(3): 304-10.

12. Basrani, BR, Manek, S, Mathers, D, et al. (2010). Determination of 4-chloroaniline and its derivatives formed in the interaction of sodium hypochlorite and chlorhexidine by using gas chromatography J Endod. ; 36:312-314.

13. Kuruvilla, JR, Kamath, MP. (1998). Antimicrobial activity of $2.5 \%$ sodium hypochlorite and $0.2 \%$ chlorhexidine gluconato separately and combinated, as endodontic irrigants J Endod; 24:472-476.

14. Basrani, BR, Manek, S, Sodhi, RN, Fillery, E, Manzur, A (2007). Interaction between sodium hypochlorite and chlorhexidine gluconate. J Endod. ; 33:966-969.

15. Bui TB, Baumgartner JC, Mitchell JC (2008). Evaluation of the interaction between sodium hypochlorite and chlorhexidine gluconate and its effect on root dentin. J Endod;34(2):181-5

16. Baker R.A. (1964). Dechlorination and Sensory Control. Journal - American Water Works Association. 56 (12): 1578-1592.

17. Griese M, Hauser K, Berkemeyer M, Gordo G. (1991). Using reduce agents to eliminate chlorine dioxide and chlorine ion residuals in drinking water. J AmWaterWork Assoc; 56-61.

18. Siqueira JF, Jr., Rôças IN, Favieri A, et al. (2000). Chemo mechanical reduction of the bacterial population in the root canal after instrumentation and irrigation with $1 \%, 2.5 \%$, and $5.25 \%$ sodium hypochlorite. J Endod. ; 26:331-334.

19. Siqueira JF Jr, Lima KC, Magalhães FAC, Lopes HP, Uzeda M (1999). Mechanical reduction of the bacterial cell number inside the root canal by three instrumentation techniques. J Endodon ;25:332-5. 
20. Ercan E1, Ozekinci T, Atakul F, Gül K. (2004). Antibacterial activity of $2 \%$ chlorhexidine gluconate and $5.25 \%$ sodium hypochlorite in infected root canal: in vivo study. J Endod. Feb; 30(2):84-7.

21. Gomes BP, Martinho FC, Vianna ME. (2009). Comparison of $2.5 \%$ sodium hypochlorite and $2 \%$ chlorhexidine gel on oral bacterial lipopolysaccharide reduction from primarily infected root canals. J Endod; 35:1350-3.

22. Alves FR, Almeida BM, Neves MA. (2011). Disinfecting Ovalshaped Root Canals: Effectiveness of Different Supplementary Approaches J Endod; 37:496-501.

23. Krishnamurthy S, Sudhakaran S. (2010). Evaluation and prevention of the precipitate formed on interaction between sodium hypochlorite and chlorhexidine $\mathrm{J}$ Endod. Jul; 36(7):1154-7.

24. Siqueira JF Jr., Guimarães-Pinto T, Rôças IN (2007). Effects of chemomechanical preparation with $2.5 \%$ sodium hypochlorite and intracanal medication with calcium hydroxide on cultivable bacteria in infected root canals. J Endod. 33:800-805.

25. Vianna ME, Horz HP, Conrads G, Zaia AA, Souza-Filho FJ, Gomes BP. (2007). Effect of root canal procedures on endotoxins and endodontic pathogens Oral MicrobiolImmunol. ; 22(6): 4118.

26. Martinho FC, Gomes BP (2008). Quantification of endotoxins and cultivable bacteria in root canal infection before and after chemomechanical preparation with $2.5 \%$ sodium hypochlorite. $\mathrm{J}$ Endod.; 34(3): 268-72.

27. Gomes BP, Martinho FC, Vianna ME. (2009). Comparison of $2.5 \%$ sodium hypochlorite and $2 \%$ chlorhexidine gel on oral bacterial lipopolysaccharide reduction from primarily infected root canals. J Endod; 35:1350-3.
28. Martinho FC, Chiesa WM, Marinho AC, Zaia AA, Ferraz CC, Almeida JF, Souza-Filho FJ, Gomes BP (2010). Clinical investigation of the efficacy of chemomechanical preparation with rotary nickel-titanium files for removal of endotoxin from primarily infected root canals. J Endod.; 36(11): 1766-9.

29. Siqueira JF Jr, Rôças IN (2010); Microbiology and treatment of endodontic infections. In: Hargreaves, K. M.Cohen, S. (Ed.). Cohen's pathways of the pulp. St. Louis: Mosby/Elsevier; 559600.

30. Rôças IN, Siqueira JF Jr. (2011b). In vivo antimicrobial effects of endodontic treatment procedures as assessed by molecular microbiologic techniques. J Endod.; 37(3): 304-10.

31. Vajrabhaya L, Sangalungkarn V, Srisatjaluk R, Korsuwannawong S, Phruksaniyom C. (2017) Hypochlorite solution for root canal irrigation that lacks a chlorinated odor. European Journal of Dentistry.11 (2):221-225.

32. Hedge J, Bashetty K, Krishnakumar, Gulati U (2012). Quantity of sodium thiosulfate required to neutralize various concentrations of sodium hypochlorite. Asian J. Pharm. Hea. Sci.; 2(3).

33. Chávez de Paz LE, Bergenholtz G, Dahlén G, Svensater G (2007). Response to alkaline stress by root canal bacteria in biofilms. Int Endo J. 40, 344-355.

34. Boal A, Patsalis F (2017). Use of Sodium Thiosulfate to Quench Hypochlorite Solutions Prior to Chlorate Analysis; 1: 04-15.

35. ORHAN, EkimOnur et al. (2016). Does para-chloroaniline really form after mixing sodium hypochlorite and chlorhexidine? Journal of endodontics, 42(3): 455-459.

36. Khatib MS, Ameer B, Ajit Mannur N, Ramalingaiahsetty AM, Peerzade SM, Bambawale A.(2020). Decoding the Perplexing Mystery of Para-Chloroaniline Formation: A Systematic Review. J Int Soc Prev Community Dent.; 10(2):142-147.
This work is licensed under Creative Commons Attribution 4.0 License

To Submit Your Article Click Here: Submit Article

DOI: $10.31579 / 2640-1045 / 051$
Ready to submit your research? Choose Auctores and benefit from:

$$
\begin{aligned}
& \text { *ast, convenient online submission } \\
& \text { rigorous peer review by experienced research in your field } \\
& \text { *apid publication on acceptance } \\
& \text { * authors retain copyrights } \\
& \text { * unique DOI for all articles } \\
& \text { immediate, unrestricted online access }
\end{aligned}
$$

At Auctores, research is always in progress.

Learn more www.auctoresonline.org/journals/endocrinology-anddisorders 